\title{
Ontogenetic variations and feeding habits of a Neotropical annual fish from southern Brazil
}

\author{
Tatiana S. Dias ${ }^{1}$, Ricardo J. Stein² \& Clarice B. Fialho'
}

\begin{abstract}
1. Programa de Pós-Graduação em Biologia Animal, Universidade Federal do Rio Grande do Sul, Departamento de Zoologia, Laboratório de Ictiologia, Av. Bento Gonçalves, 9500 Bloco IV, Prédio 43435, sala 104, 91501-970 Porto Alegre, RS, Brazil. (ts_dias@yahoo.com.br, cbfialho@pro.via-rs.com.br) 2. Faculdade Murialdo, Núcleo de Pesquisas FAMUR Selvagem, Rua Marquês do Herval, 701, 95020-260 Caxias do Sul, RS, Brazil. (ricardo.stein@faculdademurialdo.com.br)
\end{abstract}

Received 18 August 2016

Accepted 20 January 2017

DOI: 10.1590/1678-4766e2017020

\begin{abstract}
Knowing the feeding biology of a population and its ontogenetic aspects can help in understanding the functioning of fish assemblages, essential to the conservation of the habitat biodiversity in which these species are found. Annual fishes complete their life cycle in temporary aquatic environments, existing in adult stage only for brief annual periods. Changes in the feeding habits between different size classes could indicate that a species belongs to different feeding groups in different growth phases. The aim of this work was to characterize the diet of Cynopoecilus fulgens Costa, 2002 in a temporary flooded area in the coastal plain of southern Brazil, taking into consideration possible alterations in feeding habits in different body size classes caused by ontogenetic changes, to explain the coexistence of these individuals in a short space of time. The diet analysis indicated that $C$. fulgens is a generalist, consuming small crustaceans and autochthonous insects. Intraspecific differences in diet were determined when compared between nine classes of standard length. Adults fed mainly on autochthonous insects, and juveniles ingested mostly crustaceans, with the population being separated into two trophic groups: invertivores and invertivores with a tendency towards zooplanktivory. It is possible to conclude that the ontogenetic changes in the diet of $C$. fulgens are related to morphological restrictions due to the size of the individuals, since feeding competitive relations are probably not so evident.
\end{abstract}

KEYWORDS. Cynopoecilus fulgens, invertivory, intraspecific feeding overlap, generalist feeding strategy.

RESUMO. Variações ontogenéticas e hábitos alimentares de um peixe anual Neotropical do sul do Brasil. Conhecer a biologia alimentar de uma população e seus aspectos ontogenéticos podem auxiliar na compreensão do funcionamento de assembleias de peixes, fundamental para a conservação da biodiversidade do habitat no qual estas espécies são encontradas. Peixes anuais completam seu ciclo de vida em ambientes aquáticos temporários, sendo encontrados no estágio adulto somente em breves períodos anuais. Mudanças nos hábitos alimentares entre diferentes classes de tamanho podem indicar que uma espécie pertence a distintos grupos alimentares nas diferentes fases do crescimento. Este trabalho teve como objetivo caracterizar a dieta de Cynopoecilus fulgens Costa, 2002 em uma área temporariamente alagada na planície costeira sul-riograndense, levando em consideração possíveis alterações nos hábitos alimentares nas diferentes classes de tamanho corporal causadas por mudanças ontogenéticas, visando explicar a coexistência destes indivíduos em um curto espaço de tempo. A análise da dieta indica que C. fulgens é uma espécie generalista, ingerindo pequenos crustáceos e insetos autóctones. Diferenças intraespecíficas na composição da dieta foram verificadas quando comparadas entre as nove classes de comprimento padrão estabelecidas. Adultos se alimentaram principalmente de insetos autóctones, enquanto os juvenis ingeriram principalmente crustáceos, sendo a população separada em dois grupos tróficos: invertívoros e invertívoros com tendência à zooplanctivoria. É possível concluir que as mudanças ontogenéticas na dieta de $C$. fulgens estejam relacionadas a restrições morfológicas decorrentes do tamanho dos indivíduos, já que as relações competitivas, em termos alimentares, não são aparentemente tão evidentes.

PALAVRAS-CHAVE. Cynopoecilus fulgens, invertivoria, sobreposição alimentar intraespecífica, estratégia alimentar generalista.

Annual fishes belong to a diversified group of Cyprinodontiformes, represented in the Americas by the Cynolebiidae family (previously Rivulidae), which are small-sized and generally sexually dimorphic and dichromatic (CosTA, 2008). The so-called annual fishes complete their entire life cycle in temporary aquatic environments, found in the adult stage only during short annual periods, rapidly reaching sexual maturity and spawn (MYERs, 1952; COSTA, 1995, 1998, 2003; KePPELER et al., 2013). As the temporary ponds dry out and these individuals slowly die, their eggs deposited in the sediment remain in diapause (VAZ-FERREIRA et al., 1966; Wourms, 1972). When the rains return after a few months, those eggs hatch, and the fishes show a rapid developmental rate and reach sexual maturity in a few months (LOUREIRO \& DE SÁ, 1996).

Annual fishes are the most remarkable and abundant top predators in temporary habitats, presenting a generalist diet composed mainly of aquatic organisms, constituting a very important component of this type of ecosystem (LAUFER et al., 2009; POLAČIK \& ReICHARD, 2010). The same biological characteristics that allow annual fishes to live in temporary habitats, make them highly vulnerable to anthropic impacts, 
such as drainage of wet areas for agriculture purposes and urbanization (REIS et al., 2003; RosA \& LIMA, 2008; LANÉS \& MaltchiK, 2010). The majority of annual fish species deserves particular attention with respect to their conservation status due to their high degree of endemism, which increases their vulnerability (GonçALVES et al., 2011). Considering the rapid environmental degradation and the little scientific knowledge of annual fishes, there is an urge of ecological studies that provide scientific support for the development of conservation programs for these temporary environments (MALTCHIK et al., 2010).

Despite the large diversity of the Cynolebiidae family (COSTA, 2008) and the vulnerability of some species (REIS et al., 2003; RosA \& LiMA, 2008), ecological characteristics such as feeding, reproduction, behavior patterns, growth, species richness and abundance of annual fishes in temporary environments are poorly known (ARENZON et al., 1999, 2001, 2002; ERrea \& DanUlat, 2001; Shibatta \& Rocha, 2001; SHIBATTA, 2005, 2006; GARCÍA et al., 2008; LAUFER et al., 2009; Arim et al., 2010; GonÇALVES et al., 2011; VolCAN et al., 2011; CANAVERO et al., 2013; LANÉs et al., 2013, 2014a, b, 2016; KePPELER et al., 2013, 2015; ORTIZ \& ARIM, 2016).

Cynopoecilus fulgens Costa, 2002 (a senior synonym of C. multipapillatus according to CosTA (2016) and CosTA et al. (2016)), is distributed in the northern coastal plain of State of Rio Grande do Sul (RS) and southern of State of Santa Catarina (SC) (Costa, 2002b). This species inhabit temporary ponds, including semipermanent wetlands, associated to rivers and lakes, where they are extremely abundant in mid-water (Costa, 2002b; VolCAN et al., 2015). Studies on $C$. fulgens covering aspects of life history, embryonic development and toxicity have been conducted in a temporary water body in Tramandaí (RS) (ARENZON et al., 1999, 2001, 2002, 2003) and in temporary ponds in Parque Nacional da Lagoa do Peixe (RS) (LANÉs et al., 2014b, 2016). However, to our knowledge, there is only a few information on the trophic ecology of this species (KEPPELER et al., 2013, 2015)..

The feeding abilities frequently change during the fish ontogeny, mainly due to modifications in body characteristics that could determine physical restrictions on the prey size and consequent feeding selectivity (WAINWRIGTH \& RichARD, 1995; ARIM et al., 2010; KEPPELER et al., 2013, 2015). Changes in feeding resources choices could indicate that a species belongs to different trophic niches in specific phases of its ontogeny (REZSU \& SPECZIÁR, 2006). Therefore, individuals of a population with similar body sizes probably might have similar levels of capture and preferences for prey, will be capable of utilizing the same range of resources, and will interact more competitively than those with different body sizes (SANTOS-FILHO, 1997). There is special interest in knowing which size classes show greater propensity for competition, since the partition of intraspecific resources has been generally neglected in ecological and population studies (WERner \& Gilliam, 1984; Persson, 1987).

Assuming that biological characteristics (e.g. feeding habits) interfere directly with population dynamics and represent basic information of the bionomics of a species (HuGHES, 1993), knowing the feeding biology of a fish population and its ontogenetic aspects can help in understanding the functioning of an assemblage, essential for the conservation of the biodiversity of their habitat. Considering the biological characteristics of annual fishes, their vulnerability to habitat loss and the scarcity of ecological information for the majority of these species, the aim of this study was to characterize the diet of $C$. fulgens in a temporary flooded area in the coastal plain of State of Rio Grande do Sul, taking into consideration possible changes in feeding habits in different body size classes caused by ontogenetic changes, explaining the coexistence of these individuals in a short space of time, since it is an annual species.

\section{MATERIAL AND METHODS}

Study area. The coastal plain of State of Rio Grande do Sul is inserted in the Pampa Biome, characterized by subtropical grasslands, with floristic components of the southern Atlantic Forest, composed by largely pioneer species and restinga forests fragments (INSTITUTO BRASILEIRO DE GeOgrafia E EstatísticA, 2004). This region is considered of extreme biological importance and one of the prioritized areas for conservation in Brazil due to its heterogeneous and productive environments, with high biological diversity and endemism of ichthyic species (Ministério Do MeIO Ambiente, 2000; Ministério do Meio Ambiente/Secretaria de Biodiversidade e Florestas, 2006; Volcan et al., 2010).

The Lagoa dos Barros, also known as Lagoa Bacopari, is located in the municipality of Mostardas, along the southern border of the Rio Tramandaí basin (Fig. 1). The sampling site $\left(30^{\circ} 31^{\prime} 48.07^{\prime} \mathrm{S}, 50^{\circ} 25^{\prime} 29.58^{\prime \prime} \mathrm{W}\right)$ is situated in the southeast bank of Lagoa dos Barros, temporarily flooded in periods of heavy rains. The sampled area is shallow with muddy substrate, occupied by abundant submersed aquatic vegetation and surrounded by grasses around the margins (Fig. 2). The hydroperiod of the temporary flooded area varied over the

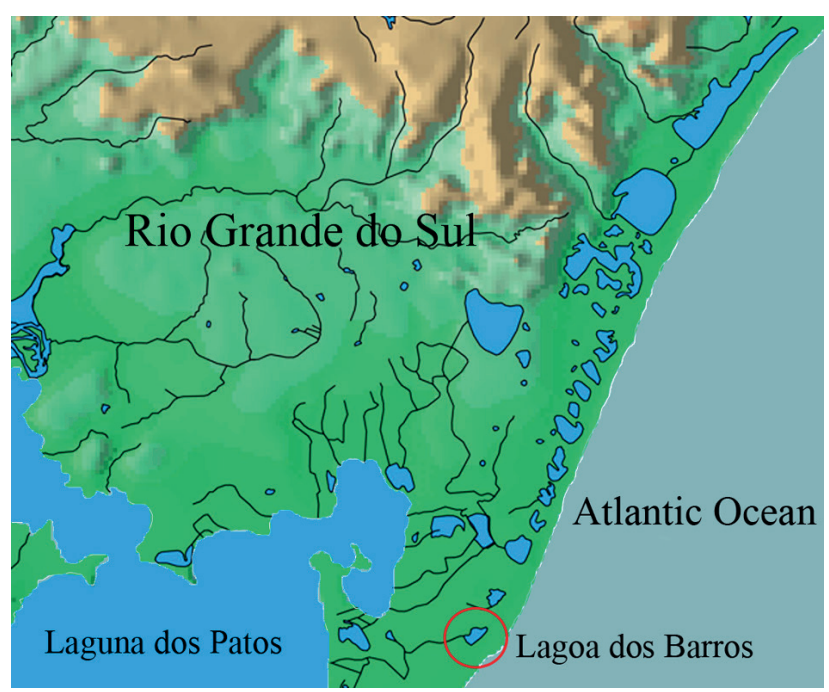

Fig. 1. Map of the study area, showing Lagoa dos Barros, municipality of Mostardas, State of Rio Grande do Sul, Brazil. 
year, with the largest volume of rain occurring between July and November of 2010 (during winter and spring seasons), when the rain volume superceded losses from evaporation. During spring, as the air temperature increased, the volume of water began to decrease until the temporary flooded area dried up completely.

Sampling. Cynopoecilus fulgens specimens were collected monthly, between July and November of 2010. No samplings were conducted in other months due to the lack of surface water in this temporary flooded area. Samplings were carried out during daylight, at a depth of approximately $40 \mathrm{~cm}$, with seine nets measuring $10 \mathrm{~m}$ in length and $2.5 \mathrm{~m}$ in height, with a mesh of $0.5 \mathrm{~cm}$. Specimens were euthanized with Eugenol (clove oil, $70 \mathrm{mg} / \mathrm{L}$ ) and fixed in $10 \%$ formalin solution at the sampling site. In the laboratory, specimens were transferred to $70 \%$ alcohol, and the standard length (SL) and the intestine length (IL) (both in millimeters) were recorded for each individual. Voucher specimens were deposited in the ichthyological collection of the Departamento de Zoologia, Universidade Federal do Rio Grande do Sul (UFRGS 16220).

Data analysis. The stomach contents of $C$. fulgens were analyzed using a stereomicroscope, and food items identified up to the lowest taxonomic level possible with the help of specific literature (NeEDHAM \& NeEDHAM, 1978; MCCAFFERTY, 1981; Mugnai et al., 2009).

The food items were grouped into taxonomic and/ or ecological categories, as follows: Mollusca, Annelida, Crustacea, Arachnida, autochthonous insects (larvae of Coleoptera, larvae and pupae of Diptera, larvae of Ephemeroptera, adults of Heteroptera, larvae of Odonata, larvae of Trichoptera, larvae of Plecoptera and parts of autochthonous insects), allochthonous insects (adults of Diptera and Plecoptera and parts of allochthonous insects), fish and scales, and material of plant origin (plant matter, seeds and filamentous algae) according to DiAs \& FiALHO (2009, 2011).

The stomach content analysis was based on the frequency of occurrence (Fo, calculated considering the number of stomachs containing a particular food category in relation to the total number of stomachs) (HYNES, 1950) and volumetric frequency (Vo, estimated taking into consideration the quantitative contribution of each item, determined by the number of checkered squares occupied by each item millimeter on ruled paper, in relation to the total number of squares occupied by all items) (HysLOP, 1980). The relative importance of each food category was established according to the feeding index (IAi) (KAWAKAMI \& VAZZOLER, $1980)$, calculated according to the formula: $\mathrm{IAi}=\left[\left(\mathrm{Fo}_{\mathrm{i}} \mathrm{X}\right.\right.$ $\left.\left.\mathrm{Vo}_{\mathrm{i}}\right) / \Sigma\left(\mathrm{Fo}_{\mathrm{i}} \times \mathrm{Vo}_{\mathrm{i}}\right)\right] \times 100$, where $\mathrm{i}=$ food item; $\mathrm{Fo}=$ frequency of occurrence; and $\mathrm{Vo}=$ volumetric frequency.

The diets of males and females of $C$. fulgens were compared by the Spearman correlation test utilizing the Vo values. A positive and significant Spearman coefficient value was expected if the items occurred in the same order of importance for males and females.

A comparative analysis of $C$. fulgens diet, according according to SL class, was carried out to determine the

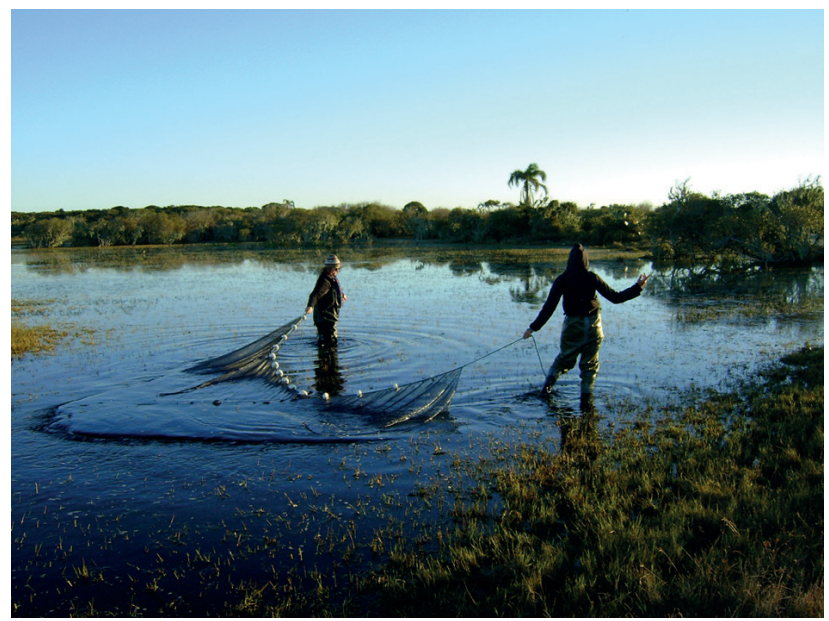

Fig. 2. General view of the sampling points of Cynopoecilus fulgens Costa, 2002 in a temporary flooded area in the coastal plain of State of Rio Grande do Sul, Brazil.

putative influence of body size on feeding habits. The SL classes were defined by the Sturges' method (VIEIRA, 1991), with the specimens being divided into nine SL classes, as follows: SL1 $(n=19)$, less than $15.99 \mathrm{~mm}$; SL2 $(\mathrm{n}=39)$, between 16 and $18.85 \mathrm{~mm}$; SL3 $(\mathrm{n}=38)$, between 18.86 and $21.71 \mathrm{~mm}$; SL4 $(\mathrm{n}=81)$, between 21.72 and $24.57 \mathrm{~mm}$; SL5 $(\mathrm{n}=61)$, between 24.58 and $27.43 \mathrm{~mm}$; SL6 $(\mathrm{n}=34)$, between 27.44 and $30.29 \mathrm{~mm}$; SL7 $(\mathrm{n}=47)$, between 30.3 and $33.15 \mathrm{~mm}$; SL8 $(\mathrm{n}=35)$, between 33.16 and 36.01 ; and SL9 $(\mathrm{n}=12)$, over $36.02 \mathrm{~mm}$ (Tab. I). Through observation of gonadal development and/or secondary sexual characteristics, and according to ArENZON et al. (1999), the individuals here classified among the classes SL1 and SL3 represent the juveniles in initial and intermediate developmental phases, while the individuals belonging to the SL4 and SL9 classes are the mature adults in advanced developmental phases.

The diet food items proportions in the different SL classes of $C$. fulgens was evaluated on the basis of Fo and Vo values combined in the graphic method proposed by Costello (1990), modified by AMUNDSEn et al. (1996). This method consists in a bi-dimensional representation of Vo (abundance) values on the y-axis, and Fo (frequency) values on the $\mathrm{x}$-axis.

To test for ontogenetic differences in the diet of $C$. fulgens between the SL classes, a similarity matrix was generated on the basis of the Bray-Curtis coefficient for the food items using the Vo values. This matrix was used on a non-metric multidimensional scaling analysis (nMDS) with overlap of complete linkage clustering. The data were evaluated by the method of analysis of similarity (ANOSIM), with the food items as samples and the SL classes as factors. ANOSIM compares the similarity between two or more groups or sampling units (factors, in the case of SL classes) and generates a statistic $\mathrm{R}$, which varies between -1 and +1 (Clarke \& Gorley, 2006). An R value of zero represents the null hypothesis (there are no differences between the set of samples), meaning that similarities within and between samples were the same, and an $\mathrm{R}$ value of 1 indicates that 
the set of samples (the contribution of the items) between the size classes (factors) were more similar between them than between the levels of each factor. The similarity of percentage (SIMPER) was also determined, using the food items as samples and SL classes as factors. SIMPER analysis was utilized to identify which food item contributed on the differences between the size classes. All analyses were performed with Primer v6 software (ClaRKe \& GoRLEY, 2006).

The intestinal quotient (IQ) was calculated for each size class of $C$. fulgens to identify the ontogenetic variations in response to feeding behavior (ZAVALA-CAMIN, 1996). This quotient is the result of the IL divided by the SL of the fish (KNÖPPEL, 1970; ZAVALA-CAMIN, 1996). The IQ values of the different length classes were evaluated by analysis of variance (ANOVA), assuming the prerequisites of normality and homogeneity of variances, using the Primer v6 software (Clarke \& Gorley, 2006).

The feeding specialization degree in each size class of C. fulgens was determined by calculating the trophic niche breadth by Levins' index measure (KREBS, 1989) utilizing the Vo values. The formula of HURLBERT (1978) was applied to standardize the measure of trophic niche, that can vary from 0 to 1 , according to the formula: $\mathrm{Ba}_{i}=\left\{[1 /(\mathrm{n}-1)] /\left[\left(1-\mathrm{S}_{j} \mathrm{p}_{i j}{ }^{2}\right)-1\right]\right\}$, where: $\mathrm{Ba}_{i}=$ Levins' standardized index for predator $i ; \mathrm{p}_{i j}$ $=$ proportion of the diet of predator $i$ that consists of prey $j$; and $n=$ total number of food items. Trophic niche breadth can vary as follows: high $(>0.61)$, intermediate $(0.41$ to 0.6$)$ and low (<0.4) (NovaKowski et al., 2008).

Food overlap was determined by paired comparisons between the length classes of $C$. fulgens using the simplified Morisita index (KREBS, 1989). Food overlap index varied from 0 , when the diets are completely different, to 1 , when they showed the same importance of items. According to ZARET \& RAND (1971) and AMUNDSEN et al. (2003), a value equal to or greater than 0.6 indicates a significant overlap in diets.

\section{RESULTS}

A total of 366 specimens of $C$. fulgens were collected, including 218 males (SL between 13.57 and $39.54 \mathrm{~mm}$ ) and 148 females (SL between 13.14 and $35.19 \mathrm{~mm}$ ). The monthly distribution of different size classes is shown in table I. The abundance of juveniles (SL1, SL2 and SL3) tends to decrease from July to September, while the adults (SL4 to SL9) increase in abundance from September (Fig. 3).

Cynopoecilus fulgens showed a wide spectrum of consumed food items. Its diet was composed by 25 different items, of which 23 and 18 were found in the stomach contents of males and females, respectively (Tab. II). The Spearman correlation test indicated that the diets of males and females were similar in volume $\left(\mathrm{r}_{\mathrm{s}}=0.8667, \mathrm{p}<0.01\right)$, indicating that there were no significant differences in feeding habits between sexes.

In general, C. fulgens fed mainly on crustaceans (for the most part Cladocera, Copepoda and Amphipoda) and on autochthonous insects (especially larvae of Diptera and Odonata), complemented by molluscs (Gastropoda), allochthonous insects (adults of Heteroptera) and plant material (plant matter, seeds and filamentous algae). Subtle differences in diet composition were found between the nine established SL classes (Tab. III), especially between juveniles (SL1 to SL3) and adults (SL4 to SL9). The most abundant food items in the stomach of the first length classes (SL1 to SL3) were crustaceans $(67.63 \%, 60.82 \%$ and $53.93 \%$, respectivelly), followed by autochthonous insects $(30.1 \%$, $37.44 \%$ and $41.54 \%$, respectivelly). The same pattern was observed with respect to food importance: crustaceans were the most important food item in the first length classes (SL1 to SL3) $(81.58 \%, 71.1 \%$ and $60.45 \%$, respectivelly), followed by autochthonous insects $(18.15 \%, 28.79 \%$ e $38.58 \%$, respectivelly), characterizing an invertivory feeding habit with a tendency towards zooplanktivory. The fourth SL

Tab. I. Sampled individuals of Cynopoecilus fulgens Costa, 2002 separated by sex and size classes (SL) in a temporary flooded area in the coastal plain of State of Rio Grande do Sul, Brazil.

\begin{tabular}{|c|c|c|c|c|c|c|}
\hline $\begin{array}{l}\text { Standard } \\
\text { Lenght }\end{array}$ & $\operatorname{sex}$ & July & August & September & October & November \\
\hline \multirow{2}{*}{ SL1 } & $\mathrm{F}$ & 7 & 9 & 1 & 0 & 0 \\
\hline & $\mathrm{M}$ & 2 & 0 & 0 & 0 & 0 \\
\hline \multirow{2}{*}{ SL2 } & $\mathrm{F}$ & 7 & 22 & 3 & 0 & 0 \\
\hline & M & 7 & 0 & 0 & 0 & 0 \\
\hline \multirow{2}{*}{ SL3 } & $\mathrm{F}$ & 2 & 11 & 3 & 5 & 2 \\
\hline & M & 12 & 2 & 1 & 0 & 0 \\
\hline \multirow{2}{*}{ SL4 } & $\mathrm{F}$ & 2 & 15 & 6 & 19 & 7 \\
\hline & $\mathrm{M}$ & 20 & 10 & 0 & 2 & 0 \\
\hline \multirow{2}{*}{ SL5 } & $\mathrm{F}$ & 0 & 5 & 2 & 11 & 5 \\
\hline & $\mathrm{M}$ & 9 & 13 & 2 & 11 & 4 \\
\hline \multirow{2}{*}{ SL6 } & $\mathrm{F}$ & 1 & 0 & 0 & 2 & 0 \\
\hline & M & 2 & 9 & 5 & 12 & 3 \\
\hline \multirow{2}{*}{ SL7 } & $\mathrm{F}$ & 0 & 0 & 0 & 0 & 0 \\
\hline & $\mathrm{M}$ & 0 & 22 & 4 & 19 & 2 \\
\hline \multirow{2}{*}{ SL8 } & $\mathrm{F}$ & 0 & 0 & 0 & 1 & 0 \\
\hline & $\mathrm{M}$ & 0 & 6 & 2 & 24 & 2 \\
\hline \multirow{2}{*}{ SL9 } & $\mathrm{F}$ & 0 & 0 & 0 & 0 & 0 \\
\hline & M & 0 & 2 & 0 & 9 & 1 \\
\hline
\end{tabular}


class (SL4) showed intermediate values of abundance and importance between crustaceans (46.95\% and 49.58\%) and autochthonous insects (47.49\% and $49.52 \%)$. Starting with the fifth SL class (SL5) a gradual transition was observed in values of abundance and importance. Autochthonous insects were the food consumed in greatest amount and showed the highest values of food importance (SL5: 52.93\% and 54.26\%; SL6: $57.3 \%$ and 59.69\%; SL7: 53.5\% and 53.55\%; SL8: $57.78 \%$ and $59.07 \%$; SL9: $55.15 \%$ and $58.91 \%$ ), followed by crustaceans (SL5: $42.45 \%$ and $45.1 \%$; SL6: $32.06 \%$ and 38.01\%; SL7: 40.47\% and 45.57\%; SL8: $33.15 \%$ and $38.27 \%$; SL9: $37.09 \%$ and $39.62 \%$ ), characterizing an invertivorous diet.

These ontogenetic changes in diet could also be observed with the comparison between the Fo and Vo values, as seen in the Costello graphs (shown in figure 4). Through this graphic representation, we note that juveniles (SL1 to SL3) showed a high preference for crustaceans, and that in the course of ontogenetic development, as observed in the next size classes (SL4 to SL9), starts to consume greater amounts of autochthonous insects and less crustaceans. This supports the categorization of a generalist feeding strategy for $C$. fulgens, regardless of the size class of the individuals.

Similarity analysis by non-metric multidimensional scaling (nMDS) with cluster overlap demonstrated the difference between the diet of juveniles and adults (Fig. 5). The similarity between the first length classes (SL1 and SL2) was of $88-89 \%$, and the grouping of these classes with SL3, with $78 \%$ similarity, was due to the high preference for crustaceans in juveniles (Fig. 6). The grouping of the classes SL5 and SL7 with SL4, and SL6 and SL8 with SL9, both with 95 to $98 \%$ similarity was due to the great importance of autochthonous insects in the diet. The highest similarities were found between the length classes SL6-SL8

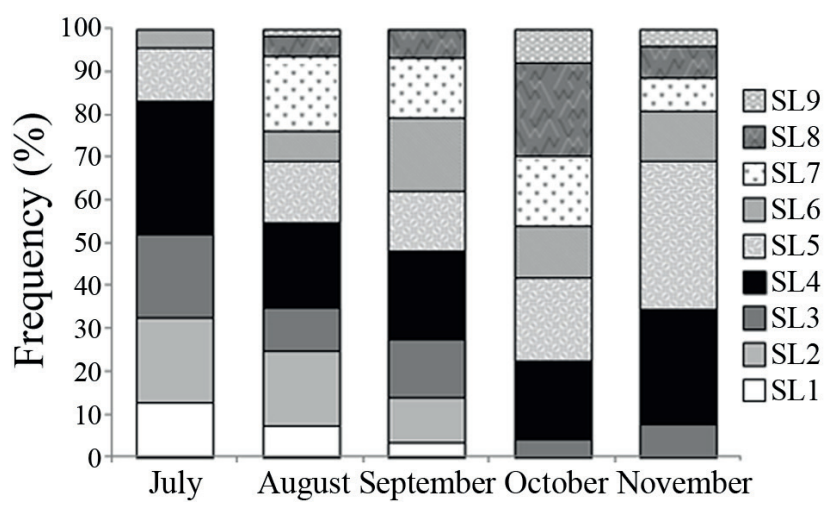

Fig. 3. Frequency (abundance) of Cynopoecilus fulgens Costa, 2002 individuals collected in a temporary flooded area in the coastal plain of State of Rio Grande do Sul, Brazil, separated in size classes for each month.

Tab. II. Frequency of occurrence (Fo\%), volumetric frequency (Vo\%) and feeding index (IAi\%) for the food items found in the diet of males and females of Cynopoecilus fulgens Costa, 2002 in a temporary flooded area in the coastal plain of State of Rio Grande do Sul, Brazil. Standard length (SL, mm) (number of stomachs analyzed): males $=13.57-39.54 \mathrm{~mm}(218)$; females $=13.14-35.19 \mathrm{~mm}(148) .{ }^{*}=$ allochthonous food items.

\begin{tabular}{|c|c|c|c|c|c|c|}
\hline \multirow{2}{*}{ Alimentary Items } & \multicolumn{3}{|c|}{ Females } & \multicolumn{3}{|c|}{ Males } \\
\hline & Fo & Vo & IAi & Fo & Vo & IAi \\
\hline \multicolumn{7}{|l|}{ Mollusca } \\
\hline Bivalvia & 0.68 & 0.06 & $<0.01$ & 0 & 0 & 0 \\
\hline Gastropoda & 10.14 & 1.95 & 0.30 & 13.31 & 4.31 & 1.06 \\
\hline \multicolumn{7}{|l|}{ Annelida } \\
\hline Hirudinea & 1.35 & 0.31 & $<0.01$ & 0.46 & 0.07 & $<0.01$ \\
\hline \multicolumn{7}{|l|}{ Crustacea } \\
\hline Amphipoda & 10.14 & 2.88 & 0.44 & 16.97 & 8.72 & 2.74 \\
\hline Cladocera & 87.84 & 28.46 & 37.66 & 74.77 & 19.82 & 27.42 \\
\hline Copepoda & 77.03 & 15.72 & 18.24 & 75.23 & 11.07 & 15.41 \\
\hline Ostracoda & 8.78 & 0.71 & 0.09 & 8.26 & 0.59 & 0.09 \\
\hline \multicolumn{7}{|l|}{ Arachnida } \\
\hline Hydracarina & 18.92 & 0.45 & 0.13 & 14.22 & 0.38 & 0.10 \\
\hline \multicolumn{7}{|l|}{ Insecta } \\
\hline Coleoptera larvae & 0.68 & 0.12 & $<0.01$ & 0 & 0 & 0 \\
\hline Diptera larvae & 70.95 & 38.58 & 41.24 & 70.18 & 36.86 & 47.87 \\
\hline Diptera pupae & 0.68 & 0.06 & $<0.01$ & 2.75 & 0.60 & 0.03 \\
\hline Diptera adult* & 0 & 0 & 0 & 0.92 & 0.12 & $<0.01$ \\
\hline Ephemeroptera nymph & 5.41 & 1.30 & 0.11 & 7.80 & 1.49 & 0.22 \\
\hline Heteroptera adult & 3.38 & 0.59 & 0.03 & 12.39 & 2.36 & 0.54 \\
\hline Odonata larvae & 14.87 & 5.69 & 1.27 & 21.10 & 8.24 & 3.22 \\
\hline Trichoptera larvae & 8.11 & 1.05 & 0.13 & 17.89 & 2.96 & 0.98 \\
\hline Plecoptera nymph & 1.35 & 0.14 & $<0.01$ & 1.38 & 0.21 & $<0.01$ \\
\hline Plecoptera adult* & 0 & 0 & 0 & 0.46 & 0.07 & $<0.01$ \\
\hline Autochthonous insects parts & 0 & 0 & 0 & 0.46 & 0.07 & $<0.01$ \\
\hline Allochthonous insects parts* & 0 & 0 & 0 & 0.46 & 0.10 & $<0.01$ \\
\hline Fish & 0 & 0 & 0 & 0.46 & 0.03 & $<0.01$ \\
\hline Fish scales & 0 & 0 & 0 & 6.88 & 0.53 & 0.07 \\
\hline \multicolumn{7}{|l|}{ Plant material } \\
\hline Vegetal matter & 13.51 & 1.62 & 0.33 & 11.01 & 0.99 & 0.20 \\
\hline Seeds & 4.73 & 0.31 & 0.02 & 6.42 & 0.25 & 0.03 \\
\hline Chlorophyta & 0 & 0 & 0 & 4.13 & 0.16 & 0.01 \\
\hline
\end{tabular}




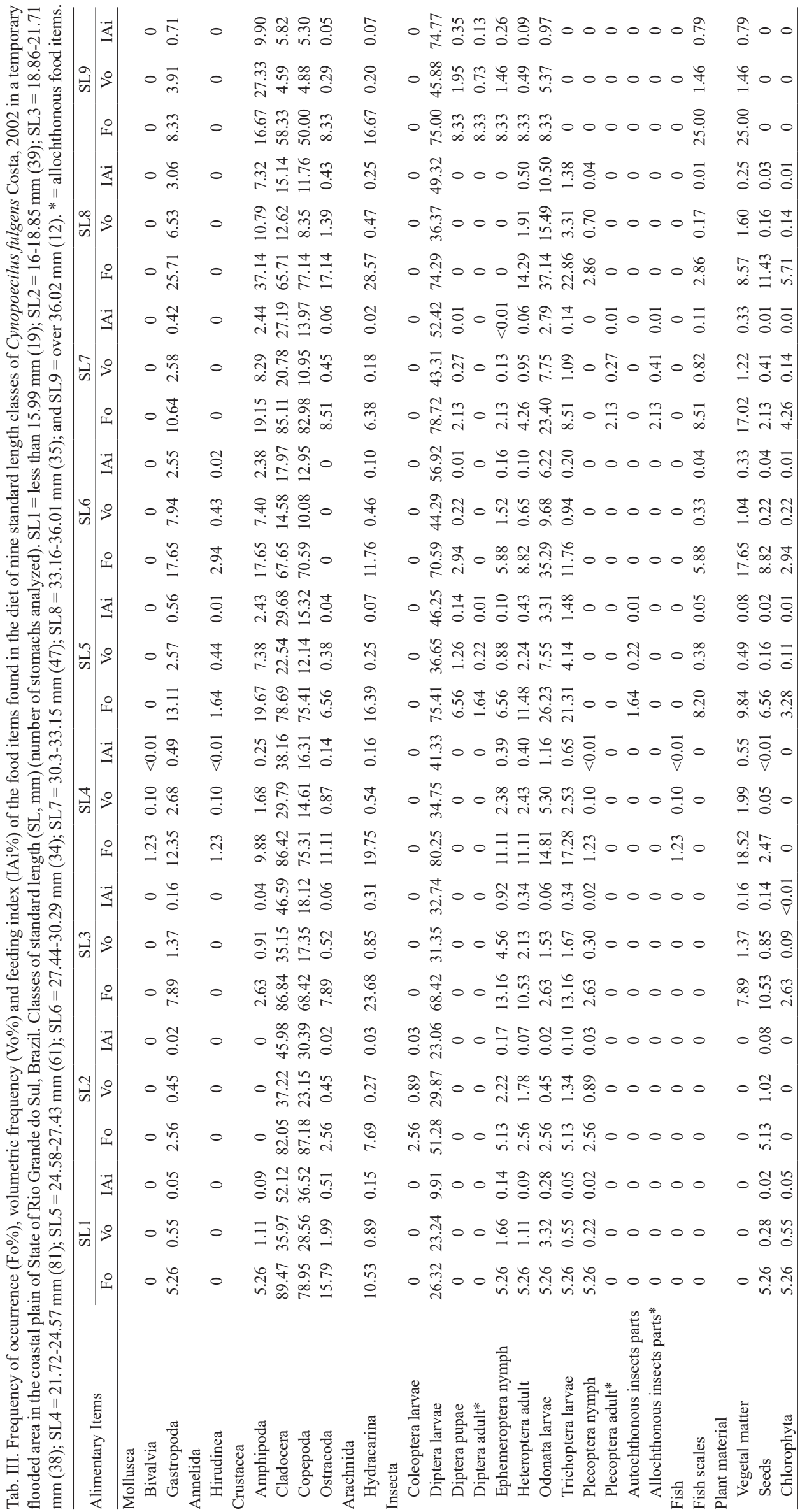



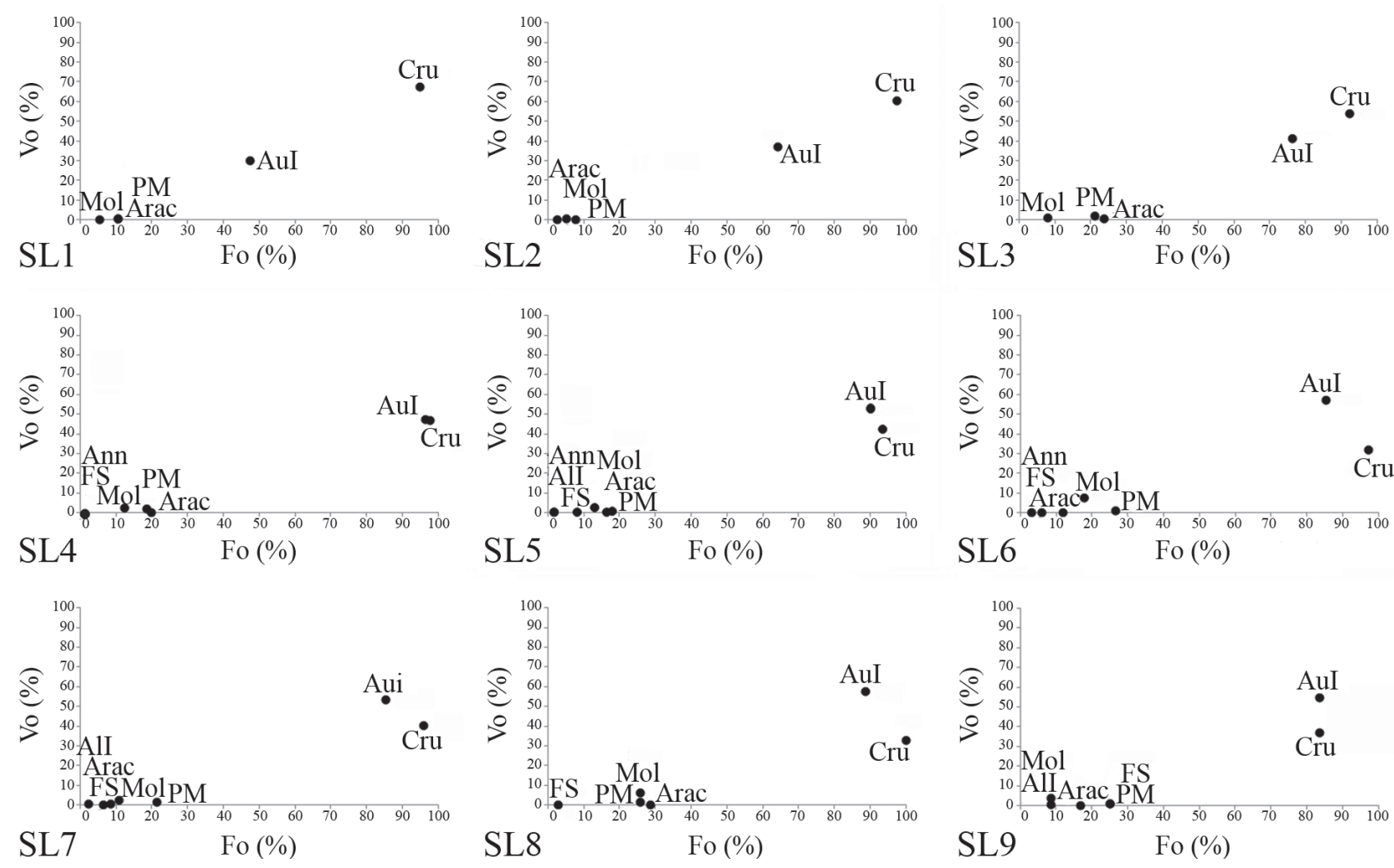

Fig. 4. Costello graphics showing the proportion of food items found in the diet of nine standard length classes of Cynopoecilus fulgens Costa, 2002 in a temporary flooded area in the coastal plain of State of Rio Grande do Sul, Brazil.

and SL5-SL7 (99\% similarity). The similarity between these classes, besides the preference for autochthonous insects in classes SL6 and SL8, occurred due to the representativity of Mollusca and Arachnida, while the similarity between SL5 and SL7 was because of the allochthonous insects and fish and scales. Multivariate analyses of the data also revealed a clear ontogenetic pattern of separation of diet composition and contribution estimated according to size class as indicated by one-way ANOSIM (global R $=0.067, \mathrm{p}<0.01$ ) (Tab. IV).

SIMPER results (Tab. V) also showed dissimilarity between the diets of the different size classes of $C$. fulgens $(42.82 \%)$, mainly due to crustaceans and autochthonous insects food items. The highest representativity of crustaceans was observed in the length classes SL1 (77.6\%), SL2 (66\%) and SL3 (58.6\%); crustaceans and autochthonous insects showed similar representativity in the diet of SL4 (49.2\% and $45.5 \%$, respectivelly), while the greatest contribution of autochthonous insects was in the diet of SL5 (49.6\%), SL6 (50.8\%), SL7 (50.8\%), SL8 (47.1\%) and SL9 (51.1\%).

During growth, C. fulgens showed morphological alteration in the intestine length/standard length ratio, as seen in the variation in the mean IQ values (Fig. 7). The intestine exhibited negative allometric growth, where it was significantly shorter in the adults $(\mathrm{F}=7.685, \mathrm{df}=8, \mathrm{p}<0.01)$.

The values of the intraspecific trophic niche breadth (Ba) are presented in figure 8. Low niche breadth was shown by the length classes SL1 to SL5 (SL1 Ba $=0.279$; SL2 Ba $=0.243 ; \mathrm{SL} 3 \mathrm{Ba}=0.352 ; \mathrm{SL} 4 \mathrm{Ba}=0.347$; SL5 Ba=0.366), while the length classes SL6 to SL9 displayed intermediate
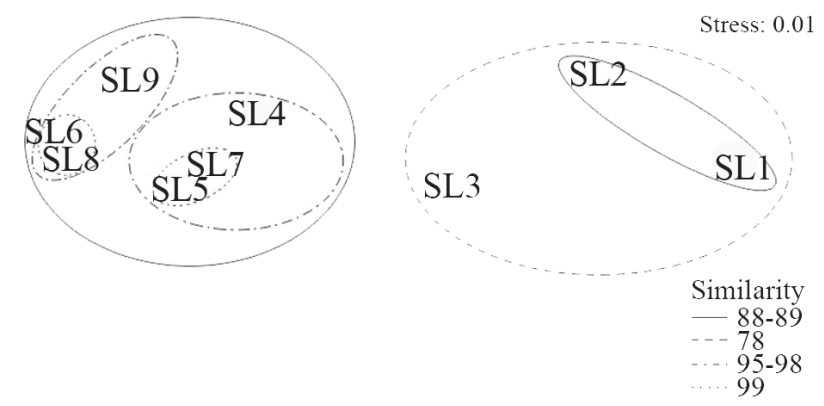

Fig. 5. Ordering according to non-metric multidimensional scaling analysis (nMDS) with cluster overlap (traces), utilizing the Bray-Curtis similarity coefficient, comparing the diets of the different standard length classes of Cynopoecilus fulgens Costa, 2002 in a temporary flooded area in the coastal plain of State of Rio Grande do Sul, Brazil.

values of niche breadth (SL6 Ba $=0.431 ; \mathrm{SL} 7 \mathrm{Ba}=0.404$; $\mathrm{SL} 8 \mathrm{Ba}=0.553$; SL9 $\mathrm{Ba}=0.511$ ), demonstrating a generalist feeding strategy for $C$. fulgens.

The intraspecific food overlap between the size classes of $C$. fulgens was high between all classes ( $>0.6)$. However, smaller values (but still representing food overlap) were observed between the smallest size class (SL1) and the largest ones (SL5 to SL9) (Tab. VI).

\section{DISCUSSION}

Despite ther higher incidence of $C$. fulgens juveniles at the beginning of the annual hydrologic cycle and the 


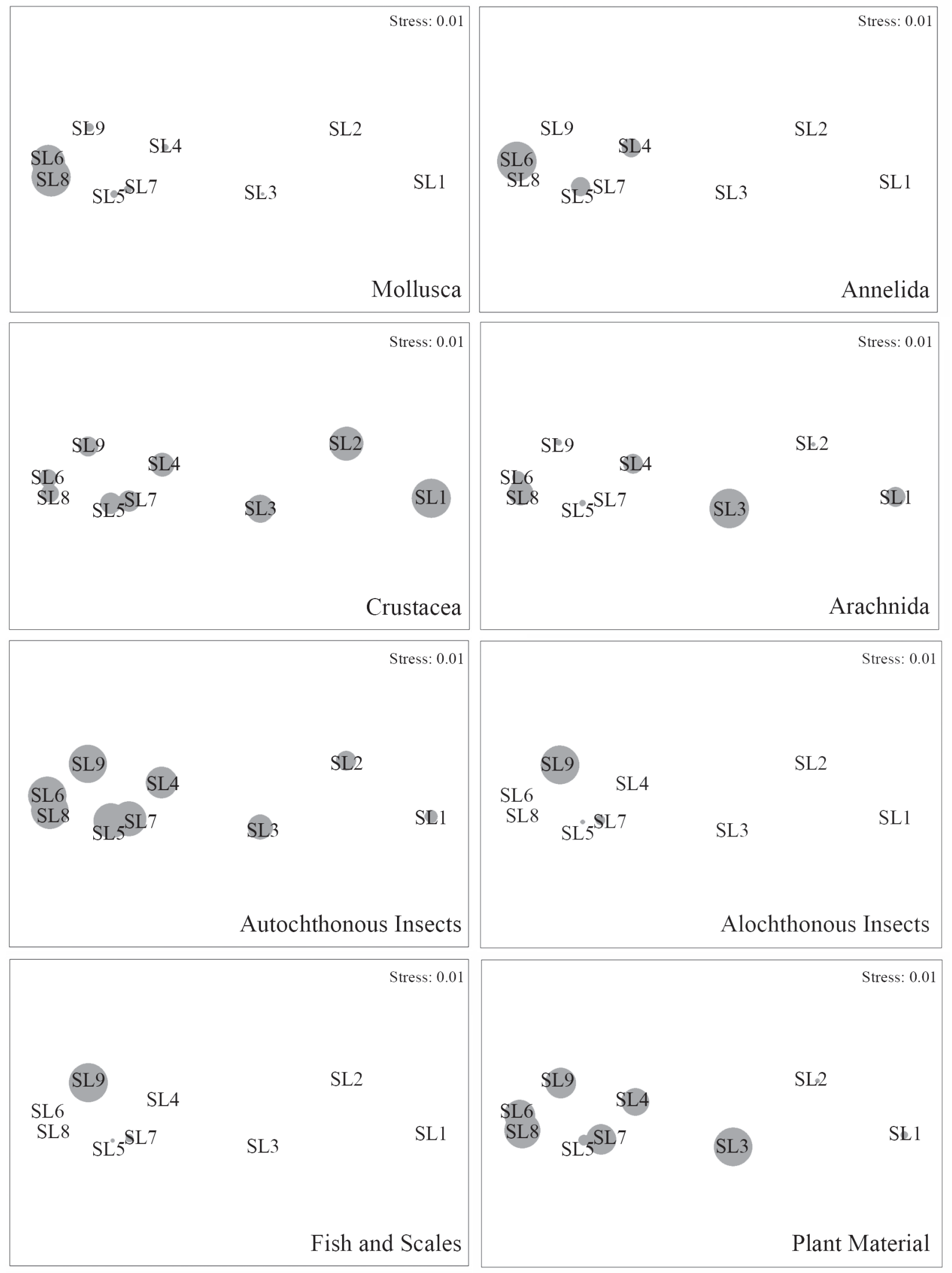

Fig. 6. Contribution of Mollusca, Annelida, Crustacea, Arachnida, autochthonous insects, allochthonous insects, fish and scales and plant material to the diet of nine standard length classes of Cynopoecilus fulgens Costa, 2002 in a temporary flooded area in the coastal plain of State of Rio Grande do Sul, Brazil, according to the ordering from non-metric multidimensional scaling analysis (nMDS) with cluster overlap. The larger the gray circle, the higher volumetric frequency values of the items. 
Tab. IV. Results of analysis of similarity (one-way ANOSIM) between the nine standard length classes of Cynopoecilus fulgens Costa, 2002 in a temporary flooded area in the coastal plain of State of Rio Grande do Sul, Brazil, showing R and p values. Global R $=0.067, \mathrm{p}<0.01$. $*=$ significant values.

\begin{tabular}{|c|c|c|c|c|c|c|c|c|c|c|}
\hline \multicolumn{2}{|c|}{$\begin{array}{l}\text { ANOSIM } \\
\text { one-way }\end{array}$} & SL1 & SL2 & SL3 & SL4 & SL5 & SL6 & SL7 & SL8 & SL9 \\
\hline SL1 & $\begin{array}{l}\mathrm{R} \text { value } \\
\mathrm{p} \text { value }\end{array}$ & $\begin{array}{l}0 \\
0\end{array}$ & & & & & & & & \\
\hline SL2 & $\begin{array}{l}\mathrm{R} \text { value } \\
\mathrm{p} \text { value }\end{array}$ & $\begin{array}{c}0.394 \\
<0.001^{*}\end{array}$ & $\begin{array}{l}0 \\
0\end{array}$ & & & & & & & \\
\hline SL3 & $\begin{array}{l}\mathrm{R} \text { value } \\
\mathrm{p} \text { value }\end{array}$ & $\begin{array}{l}0.017 \\
0.253\end{array}$ & $\begin{array}{r}-0.008 \\
0.578\end{array}$ & $\begin{array}{l}0 \\
0\end{array}$ & & & & & & \\
\hline SL4 & $\begin{array}{l}\mathrm{R} \text { value } \\
\mathrm{p} \text { value }\end{array}$ & $\begin{array}{c}0.208 \\
<0.001^{*}\end{array}$ & $\begin{array}{c}0.063 \\
<0.001 *\end{array}$ & $\begin{array}{c}0.052 \\
<0.001^{*}\end{array}$ & $\begin{array}{l}0 \\
0\end{array}$ & & & & & \\
\hline SL5 & $\begin{array}{l}\mathrm{R} \text { value } \\
\mathrm{p} \text { value }\end{array}$ & $\begin{array}{c}0.141 \\
<0.001 *\end{array}$ & $\begin{array}{c}0.043 \\
<0.001 *\end{array}$ & $\begin{array}{l}0.018 \\
0.157\end{array}$ & $\begin{array}{l}0.021 \\
0.075\end{array}$ & $\begin{array}{l}0 \\
0\end{array}$ & & & & \\
\hline SL6 & $\begin{array}{l}\mathrm{R} \text { value } \\
\mathrm{p} \text { value }\end{array}$ & $\begin{array}{c}0.171 \\
<0.001^{*}\end{array}$ & $\begin{array}{c}0.108 \\
<0.001 *\end{array}$ & $\begin{array}{c}0.048 \\
<0.001^{*}\end{array}$ & $\begin{array}{c}0.106 \\
<0.001 *\end{array}$ & $\begin{array}{l}0.020 \\
0.185\end{array}$ & $\begin{array}{l}0 \\
0\end{array}$ & & & \\
\hline SL7 & $\begin{array}{l}\mathrm{R} \text { value } \\
\mathrm{p} \text { value }\end{array}$ & $\begin{array}{c}0.199 \\
<0.001^{*}\end{array}$ & $\begin{array}{c}0.081 \\
<0.001 *\end{array}$ & $\begin{array}{c}0.038 \\
<0.001^{*}\end{array}$ & $\begin{array}{c}0.041 \\
<0.001^{*}\end{array}$ & $\begin{array}{r}-0.007 \\
0.614\end{array}$ & $\begin{array}{l}0.001 \\
0.398\end{array}$ & $\begin{array}{l}0 \\
0\end{array}$ & & \\
\hline SL8 & $\begin{array}{l}\mathrm{R} \text { value } \\
\mathrm{p} \text { value }\end{array}$ & $\begin{array}{c}0.256 \\
<0.001^{*}\end{array}$ & $\begin{array}{c}0.118 \\
<0.001 *\end{array}$ & $\begin{array}{c}0.059 \\
<0.001^{*}\end{array}$ & $\begin{array}{l}0.061 \\
0.052\end{array}$ & $\begin{array}{l}0.013 \\
0.271\end{array}$ & $\begin{array}{r}-0.005 \\
0.492\end{array}$ & $\begin{array}{r}-0.003 \\
0.480\end{array}$ & $\begin{array}{l}0 \\
0\end{array}$ & \\
\hline SL9 & $\begin{array}{l}\mathrm{R} \text { value } \\
\mathrm{p} \text { value }\end{array}$ & $\begin{array}{c}0.260 \\
<0.001 *\end{array}$ & $\begin{array}{c}0.251 \\
<0.001 *\end{array}$ & $\begin{array}{c}0.162 \\
<0.001^{*}\end{array}$ & $\begin{array}{c}0.241 \\
<0.001 *\end{array}$ & $\begin{array}{c}0.124 \\
<0.001^{*}\end{array}$ & $\begin{array}{l}0.043 \\
0.234\end{array}$ & $\begin{array}{l}0.102 \\
0.087\end{array}$ & $\begin{array}{l}0.123 \\
0.061\end{array}$ & $\begin{array}{l}0 \\
0\end{array}$ \\
\hline
\end{tabular}

Tab. V. Results of similarity percentage analysis (SIMPER), showing mean abundance values of each food item in the nine standard length classes of Cynopoecilus fulgens Costa, 2002 in a temporary flooded area in the coastal plain of State of Rio Grande do Sul, Brazil.

\begin{tabular}{|c|c|c|c|c|c|c|c|c|}
\hline & Mollusca & Annelida & Crustacea & Arachnida & $\begin{array}{c}\text { Autochthonous } \\
\text { insects }\end{array}$ & $\begin{array}{c}\text { Allochthonous } \\
\text { insects }\end{array}$ & $\begin{array}{c}\text { Fish/ } \\
\text { Fish scales }\end{array}$ & $\begin{array}{c}\text { Plant } \\
\text { material }\end{array}$ \\
\hline SL1 & 0.47 & 0 & 77.60 & 0.53 & 20.90 & 0 & 0 & 0.50 \\
\hline SL2 & 0.62 & 0 & 66.00 & 0.17 & 31.50 & 0 & 0 & 1.71 \\
\hline SL3 & 0.93 & 0 & 58.60 & 0.74 & 38.00 & 0 & 0 & 1.73 \\
\hline SL4 & 2.74 & 0.05 & 49.20 & 0.64 & 45.50 & 0 & 0.07 & 1.80 \\
\hline SL5 & 2.34 & 0.33 & 46.10 & 0.27 & 49.60 & 0.24 & 0.42 & 0.70 \\
\hline SL6 & 6.19 & 0.25 & 40.40 & 0.53 & 50.80 & 0 & 0.27 & 1.56 \\
\hline SL7 & 2.82 & 0 & 41.90 & 0.15 & 50.80 & 0.91 & 1.22 & 2.20 \\
\hline SL8 & 8.78 & 0 & 40.40 & 1.12 & 47.14 & 0 & 0.18 & 2.38 \\
\hline SL9 & 8.31 & 0 & 35.50 & 0.16 & 51.10 & 0.28 & 2.67 & 1.98 \\
\hline
\end{tabular}

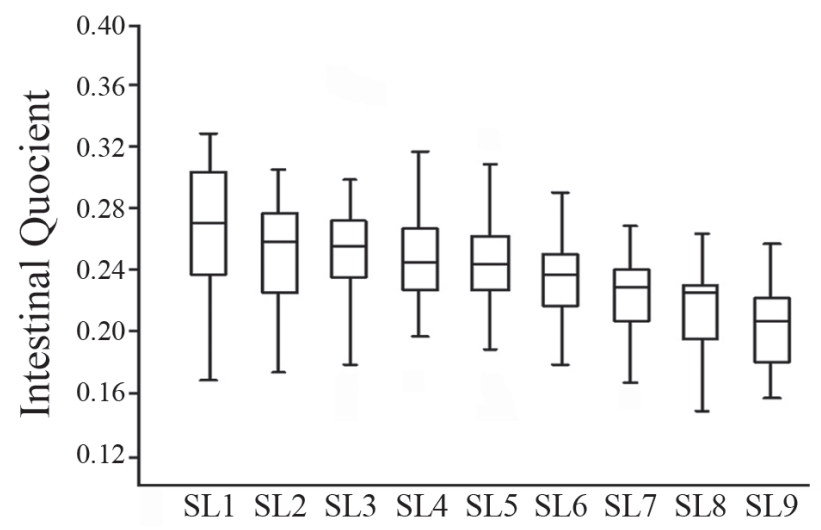

Fig. 7. Intestinal quotient values determined for nine standard length classes of Cynopoecilus fulgens Costa, 2002 in a temporary flooded area in the coastal plain of State of Rio Grande do Sul, Brazil.

majority of adults at the end of this period, individuals of all size classes were sampled in almost every month, suggesting an asynchrony in hatching times resulting in multiple cohorts per year (WARD et al., 2006). As pointed by Arenzon et al. (1999), C. fulgens does not present a

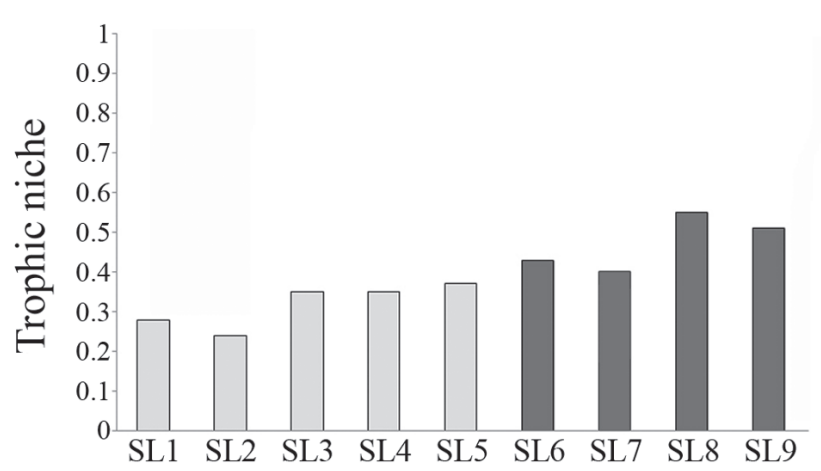

Fig. 8. Trophic niche breadth values calculated by Levins index $(\mathrm{Ba})$ for the diet of nine classes of standard length of Cynopoecilus fulgens Costa, 2002 in a temporary flooded area in the coastal plain of State of Rio Grande do Sul, Brazil (SL1 Ba =0.279; SL2 Ba =0.243; SL3 Ba =0.352; SL4 Ba = 0.347; SL5 Ba =0.366; SL6 Ba $=0.431$; SL7 Ba =0.404; SL8 Ba=0.553; and SL9 $\mathrm{Ba}=0.511)$. Gray bars indicate a small niche breadth, while the black bars indicate an intermediate niche breadth.

specific reproductive period, spawning continuously over a prolonged time, that is, the recruitment is continuous. Thus, rapid gonadal development, prolonged reproductive period, continuous egg production and spawning, and the diapause process of C. fulgens are strategies that result in a "stock" 
Tab. VI. Values of food overlap index calculated from paired comparison of the nine standard length classes of Cynopoecilus fulgens Costa, 2002 in a temporary flooded area in the coastal plain of State of Rio Grande do Sul, Brazil.

\begin{tabular}{|c|c|c|c|c|c|c|c|c|c|}
\hline & SL1 & SL2 & SL3 & SL4 & SL5 & SL6 & SL7 & SL8 & SL9 \\
\hline SL1 & 1 & & & & & & & & \\
\hline SL2 & 0.983 & 1 & & & & & & & \\
\hline SL3 & 0.929 & 0.981 & 1 & & & & & & \\
\hline SL4 & 0.831 & 0.917 & 0.976 & 1 & & & & & \\
\hline SL5 & 0.779 & 0.878 & 0.952 & 0.996 & 1 & & & & \\
\hline SL6 & 0.698 & 0.812 & 0.906 & 0.976 & 0.992 & 1 & & & \\
\hline SL7 & 0.786 & 0.883 & 0.956 & 0.997 & 0.999 & 0.990 & 1 & & \\
\hline SL8 & 0.702 & 0.816 & 0.909 & 0.978 & 0.993 & 0.999 & 0.991 & 1 & \\
\hline SL9 & 0.715 & 0.826 & 0.917 & 0.981 & 0.995 & 0.999 & 0.994 & 0.999 & 1 \\
\hline
\end{tabular}

of eggs at different stages of embryonic development in the substrate. These eggs will give rise to embryo hatching flows when abiotic conditions become favorable again, producing different cohorts (ARENZON et al., 1999), causing the occurrence of individuals of all length classes in the same sampling, as observed in our study. Such asynchrony in hatching dates could be attributed to a progressive flooding of the pond, with eggs that are deposited on the deeper parts of the substrate hatching first, or as a result of the union of adjacent ponds by accumulating water at different rates and uniting in a larger pond, as seen by PoLAČIK et al. (2011), for Nothobranchius Peters, 1868 species. This strategy protects the species from a single massive hatching during a short rainy season, which would not allow the fish to mature and reproduce (ARENZON et al., 1999). In addition, factors such as intra and interspecific competition and predation could also play important roles on the observed decreased abundance in juveniles of $C$. fulgens over time (NICO \& THOMERSON, 1989; Winemiller \& JePSEN, 1998; LANÉs et al., 2014b), as detected in our study.

On the other hand, recent studies with members of the Cynolebiidae family demonstrated that there is generally an increase in individual's average size over time, without necessarily the co-occurrence of juveniles and adults in the same period, wich could indicate a hatching synchrony in these populations. LANÉs et al. (2014b, 2016) observed that the abundances of Austrolebias minuano Costa \& Cheffe, 2001 and C. fulgens in southern Brazil tended to decrease from fall to spring, while the juveniles of both species occur only in the fall and no adult was observed during this season, suggesting a single cohort. Likewise, LANÉs et al. (2012) found that the average size of Atlantirivulus riograndensis (Costa \& Lanés, 2009) in Parque Nacional da Lagoa do Peixe (RS) increased over the year, explaining that the variation in body size was related to individual growth through the year.

As a result of the sexual dimorphism in size observed in C. fulgens (also observed by ARENZON et al., 2001) and of the behavioral patterns of some species (males are territorial in some cynolebiids, according to SHIBATTA (2006)), feeding was first contrasted between males and females to determine putative differences in this character (Tab. II). Feeding differences between males and females are more evident in species with marked sexual dimorphism in size and are a widely observed phenomenon in animals (SHINE, 1989). Also, sexual morphological differences could cause a lower feeding overlap and lower intraespecific competition in some species (RUeFfer et al., 2006; COOPER et al., 2011). However, in our study, the intersexual size differences was not sufficient to result in diet differenciation, as observed by SHIBATTA \& Rocha (2001) for Simpsonichthys boitonei Carvalho, 1959 (by frequency and volume), CONTENTE \& STEFANONI (2010) for Atlantirivulus santensis (Köhler, 1906) (by volume and abundance), and GonÇALVES et al. (2011) for Cynopoecilus melanotaenia (Regan, 1912) (by frequency). These studies and our results reinforce that morphological differences in size between males and females probably did not evolve as a response to minimize intraspecific competition for food. Also, this may be occuring due to a spatial overlap between males and females, resulting in a similar prey capture situation and ability (Contente \& Stefanoni, 2010). On the other hand, LAUFER et al. (2009) for two Austrolebias species, KePPeler et al. (2013) for C. fulgens, and CAVALHeIro \& FiALHO (2016) for A. riograndensis, found differences in prey selectivity among males, females and juveniles, attributed to morphological characteristics that could predispose intersexual dissimilarities in diet.

The analysis of diet indicates that $C$. fulgens is a generalist species with an invertivorous diet. This annual fish shows a wide feeding spectrum ( 25 food items), consuming mostly small crustaceans (mainly Cladocera and Copepoda), and autochthonous insects (mainly larvae of Diptera). A generalist diet, consisting of small autochthonous invertebrates, was also found by KEPPELER et al. (2013) to C. fulgens (52 food items) and by Gonçalves et al. (2011) and LAUFER et al. (2009) to C. melanotaenia (26 and 23 food items, respectively), suggesting that this characteristic can be standard in the family (HARRINGTON \& RIVAS, 1958; HUEHNER et al., 1985; COSTA, 1987, 1998, 2009; DAVIS et al., 1990; TAYLOR, 1992; SHIBATTA \& Rocha, 2001; SHIBATTA \& BENNEMANN, 2003; Arim et al., 2010; ABILHOA et al., 2010a, b; Contente \& Stefanoni, 2010; PolačiK \& Reichard, 2010; Cavalheiro \& Fialho, 2016; Loureiro \& de Sá, 2016; ORTIZ \& ARIM, 2016). The generalist feeding strategy is an expected characteristic for the life history of $C$. fulgens and other annual fishes, since they live in temporary habitats with varied environmental conditions, conferring high resistance to changes in food resources (COSTA, 1995, 2002a; LAUFER et al., 2009; PolaČIK \& Reichard, 2010; GonÇalves et al., 2011; KePPELER et al., 2013). Moreover, there are few opportunities for feeding specialization in freshwater fishes 
(LARKIN, 1956), and generalization is especially favored when the preferred food type is available. Thereby, diet specialization would demand significant costs due to the large variation in availability of prey in these environments (GONÇALVES et al., 2011).

Ontogenetic feeding changes are well known in fishes (Wootton, 1999; AmUNDSEn et al., 2003) and have been recorded in some Cynolebiidae species (SANTOS-FiLHO, 1997; LAUFer et al., 2009; ABILHOA et al., 2010b; CANAVERO et al., 2013; KePPEler et al., 2013, 2015; CAVAlHeIro \& Fialho, 2016; OrTIZ \& ARIM, 2016). These ontogenetic changes in annual fish populations may reduce a potential intraspecific competition for prey items through diet segregation or by reducing direct interactions through spatial and/or temporal segregation (LAUFER et al., 2009; CANAVERo et al., 2013; ORTIZ \& ARIM, 2016), since is known that competitive interactions are stronger among individuals of similar body sizes (SANtos-Filho, 1997; CANAVERo et al., 2013; OrTIZ \& ARIM, 2016). The ontogenetic changes in diet between size classes of $C$. fulgens might occur as a consequence of the increase in body size (ARIM et al., 2010), and not as a response for minimize intraspecific competition in this studied population. We believe that the most important morphological changes during $C$. fulgens ontogeny are the increase of the mouth gape limitation (KEENLEYSIDE, 1979; MaGnan \& FitzGerald, 1984), handling efficiency of prey items (XuE et al., 2005) and swimming ability (Wootton, 1999; WARD et al., 2006; KEPPELER et al., 2015), allowing the consumption of a variety of food items, larger prey items and with a higher caloric content (ABELHA et al., 2001; ARIM et al., 2010). This can be interpreted in light of the theory of optimal foraging, which predicts that foragers should select prey items for optimizing their energy intake in relation to the costs of catching, ingesting and digesting these preys (PyKe et al., 1977; WeRner \& Gilliam, 1984; Gerking, 1994; WaINWRight \& RichaRd, 1995). However, the abundance of prey items in the environment would not be the only factor that would explain food selection by fishes, since the ontogenetic morphological characteristics related to capture and ingestion could explain the absence of some food items in the diet, despite their abundance in the environment (SÁNCHEZ-HERNÁNDEZ et al., 2011, 2012; SÁNCHEZ-HERNÁNDEZ \& COBO, 2012).

The greater consumption of crustaceans by juveniles was probably the main ontogenetic variation in C. fulgens diet. Juvenile fish should maximize growth and survival due to their vulnerability in the early stages of life (PilatTI \& VANNI, 2007), consuming abundant prey itens with important sources of protein and keratin, such as crustaceans (CANTOMaza \& Vega-Cendejas, 2007). Various studies have demonstrated the preference of juvenile cynolebiids for crustaceans (GONÇALVES et al., 2011; KEPPELER et al., 2013; Cavalheiro \& Fialho, 2016), probably due to the high availability of this resource, the small size of this prey and the limited agility of juvenile fish. Finally, adults of $C$. fulgens had a tendency to ingest, in addition to crustaceans, a greater amount of autochtonous insects, such as Diptera and Odonata larvae. Probably this behavior reflects the great success of the larger size classes in catching these prey items, being this efficiency in capture increased through ontogeny in response to a higher nutritional demand in adults (WAINWRIGHT \& Richard, 1995; AdriaEns et al., 2001; Ortiz \& ARIM, 2016). Thus, being known that the differentiation of trophic niches within a single population can occur through ontogeny (WerNer \& GILLIAM, 1984; WARD et al., 2006), juveniles and adults of C. fulgens was separated into two trophic groups according to body size: invertivores with a tendency towards zooplanktivory and invertivores, respectively. It is important to observe that these groups are not truly independent from each other (WoOdWARd \& Hildrew, 2002; Arim et al., 2010), since they overlap significantly in food preferences. Some studies suggest that with the increase in size of the fish, larger prey items are progressively added to the diet (e.g. insects), while small items are substituted or ingested in smaller amounts (e.g. crustaceans) (KEAST \& WEBB, 1966; Popova, 1967, 1978; LAUFer et al., 2009; Arim et al., 2010; KePPeler et al., 2013, 2015; OrTIZ \& ArIm, 2016). As a result, a large-sized adult fish feeds on all prey consumed by the juveniles, along with larger prey items that are available in the environment (WERNER \& GILLIAM, 1984; WOODWARD \& HiLDREw, 2002; RAMOS-JiLiberTo et al., 2011; OrTIZ \& ARIM, 2016), as seen in our study.

The invertivorous diet exhibited by $C$. fulgens is consistent with the low IQ values found on the different size classes, and is in agreement with the IQ values found for other cynolebiids (Shibatta \& Rocha, 2001; Gonçalves et al., 2011). It is well known that the diet influences the intestine length, with carnivorous fishes presenting a shorter intestine than herbivorous, while an intermediate length is typical of omnivorous species (AL-HussaInI, 1949; KAPOOR et al., 1975; KRAMER \& BRYANT, 1995). Intestine length can be a very useful parameter to evaluate ontogenetic changes that reflect feeding behavior (KNÖPPEL, 1970; ZaVALA-CAMIM, 1996). In C. fulgens, the intestine presented negative allometry, with lower IQ values shown by the adults (invertivorous diet) and the higher values found in juveniles (invertivorous with a tendency towards zooplanktivory) (Fig. 7). The significance of this allometry might be related to the effect of the increase on the intestine absorption capacities and be a reflection of the dietary habits and needs expressed during development (Kramer \& Bryant, 1995; Teixeira de Melo et al., 2006). Also, the intestine negative allometric growth in C. fulgens might be a result of either: the preadaptation to the invertivorous diet regardless of its stage of ontogenetic development, and/or the negative allometry observed in juveniles agrees with a general behavioral strategy, allowing to grow more in body size during a short period of time (Munch \& Conover, 2003; Teixeira de Melo et al., 2006). Also, changes in the intestine length could ensure that food will be retained longer in the digestive tract and more nutrients will be absorbed (KARACHLE \& STERGIOU, 2012). This would lead to the allocation of more energy for growth in size than in weight to reach adult stages (with a strictly invertivorous diet), since survival (SoGARD, 1997) and 
reproductive success increases with body size (RoFF, 1992).

Data on trophic niche breadth are extensively utilized to complement the study of diet composition of fish, where they are useful in the interpretation of the degree of feeding specialization or generalization of a species. The trophic niche breadth of $C$. fulgens increased during ontogeny (Fig. 8). In other words, as the fishes increased in size, they showed preference for a greater diversity of prey items becoming more generalist in relation to the type of food they selected (WINEMILler, 1989; SCHAFER et al., 2002; WoODWARD \& HiLdREW, 2002; WinemiLler \& Kelso-WinEMILLER, 2003; RAMOS-JiliberTo et al., 2011; SÁNCHEZ-HERNÁNDEZ \& CoBO, 2012; SÁNCHEZ-HeRnÁNDEZ et al., 2012; KePPELER et al., 2015). This increase in prey richness consumed by adults may be associated with the need of larger fishes to diversify their diets to support higher energy demands (ARIM et al., 2010). Also, the increase in trophic niche breadth through ontogeny probably occurred due to the increased in mouth gape limitation, better food handling and swimming capacity, characteristics directly correlated to the larger body size in adults, mentioned before.

The food resources partitioning means the division of prey items by ages or body size classes in a single species through spatial and/or temporal segregation, for the purpose of exploiting food resources to their maximum (SCHOENER, 1974; Hurlbert, 1978; Violle et al., 2012). We believe that the high feeding overlap observed among the different body size classes in C. fulgens does not necessarily imply that the intraspecific competition exists. The juveniles and adults cynolebiids with similar morphology may present segregated diets, occuping different trophic niches, or may reduce intraspecific interferences by feeding at different times and/or microhabitats, reinforcing the role of interactions influenced by body size as an important determinant in the interactions between species and the structure of the food chain in this temporary system (LAUFER et al., 2009). ARIM et al. (2010), CANAVEro et al. (2013) and ORTIZ \& ARIM (2016) observed a clear spatial segregation in annual fishes of different body size classes in temporary ponds in Uruguay, where the main determinants of the assembly structure appear to be the differences in the trophic niche and the opposing interactions between size classes. Thus, spatial segregation by body size classes could allow coexistence by reducing intraspecific interactions (CANAVERO et al., 2013), and we believe that it may be happening in the population studied here. In addition, we also believe that the available food items were sufficiently abundant (GERKING, 1994; DiAs \& FiALHO, 2009, 2011), not being the cause of competition, allowing the feeding patterns observed in C.fulgens in this temporary flooded area, although the availability of food resources was not evaluated in the present study.

Acknowledgments. The authors thank our colleagues of the Laboratório de Ictiologia (UFRGS) for their help on field work and suggestions in the course of this study.

\section{REFERENCES}

Abelha, M. C. F.; Agostinho, A. A. \& Goulart, E. 2001. Plasticidade trófica em peixes de água doce. Acta Scientiarum, Biological Sciences 23(2):425-434.

Abilhoa, V.; Vitule, J. R. S. \& Bornatowski, H. 2010a. Feeding ecology of Rivulus luelingi (Aplocheiloidei: Rivulidae) in a Coastal Atlantic Rainforest stream, southern Brazil. Neotropical Ichthyology 8(4):813818.

Abilhoa, V.; Vitule, J. R. S.; Bornatowski, H.; de Lara, F. B.; Kohler, G. U.; FestTi, L.; do Carmo, W. P. D. \& Ribeiro, I. K. 2010b. Effects of body size on the diet of Rivulus haraldsiolii (Aplocheiloidei: Rivulidae) in a coastal Atlantic Rainforest island stream, southern Brazil. Revista Biotemas 23(4):59-64.

Adriaens, D.; Aerts, P. \& Verraes, W. 2001. Ontogenetic shift in mouth opening mechanisms in a catfish (Clariidae, Siluriformes): A response to increasing functional demands. Journal of Morphology 247:197-216.

AL-Hussaini, A. H. 1949. On the functional morphology of the alimentary tract of some fish in relation to differences in their feeding habits: anatomy and histology. Quartely Journal of Microscopical Science 90(2):109-139.

Amundsen, P.; Bohn, T.; Popova, O. A.; Staldvik, F. J.; Reshetnikov, Y. S.; Kashulin, N. A. \& Lukin, A. A. 2003. Ontogenetic niche shifts and resource partitioning in a subarctic piscivore fish guild. Hydrobiology 497:109-119.

Amundsen, P. A.; Gabler, H. M. \& Staldvik, F. L. 1996. A new approach to graphical analysis of feeding strategy from stomach contents data modification of the Costello (1990) method. Journal of Fish Biology 48:607-614.

Arenzon, A.; Lemos, C. A. \& Bohrer, M. B. C. 2002. The influence of temperature on the embryonic development of the annual fish Cynopoecilus melanotaenia (Cyprinodontiformes: Rivulidae). Brazilian Journal of Biology 62(4b):743-747.

Arenzon, A.; Peret, A. C. \& Bohrer, M. B. C. 1999. Reproduction of the annual fish Cynopoecilus maelanotaenia (Regan, 1912) based on a temporary water body population in Rio Grande do Sul State, Brazil. Hydrobiologia 411:65-70.

Arenzon, A.; Peret, A. C. \& Bohrer, M. B. C. 2001. Growth of the annual fish Cynopoecilus melanotaenia (Regan, 1912) based in a temporary water body population in Rio Grande Do Sul State, Brazil (Cyprinodontiformes, Rivulidae). Revista Brasileira de Biologia 61(1):117-123.

Arenzon, A.; Pinto, R. F.; Colombo, P. \& Raya-Rodriguez, M. T. 2003. Assessment of the freshwater annual fish Cynopoecilus melanotaenia as a toxicity test organism using three reference substances. Environmental Toxicology and Chemistry 22:2188-2190.

Arim, M.; Abades, S. B.; Laufer, G.; Loureiro, M. \& Marquet, P. 2010. Food web structure and body size trophic position and resource acquisition. Oikos 119(1):147-153.

Canavero, A.; Hernández, D.; Zarucki, M. \& Arim, M. 2013. Patterns of co-ocurrences in a killifish metacommunity are more related with body size than with species identity. Austral Ecology 39(4):455-461.

Canto-Maza, W. G. \& Vega-Cendejas, M. E. 2007. Distribución, abundancia y preferencias alimenticias del pez sapo Opsanus phobetron (Batrachoididae) en la laguna costera de Chelem, Yucatán, México. Revista de Biología Tropical 55:979-988.

Cavalheiro, L. W. \& Fialho, C. B. 2016. Trophic strategy of Atlantirivulus riograndensis (Cyprinodontiformes: Rivulidae), a non-annual rivulid threatened by extinction, in a perennial environment, Brazil. Neotropical Ichthyology 14(1):183-192.

Clarke, K. R. \& Gorley, R. N. 2006. PRIMER v6: User Manual/Tutorial. Plymouth, PRIMER-E. 190p.

COntente, R. \& Stefanoni, M. 2010. Diet of the Atlantic rainforest killifish Rivulus santensis (Rivulidae, Cyprinodontiformes) in southeastern Brazil. Journal of Applied Ichthyology 26:930-932.

Cooper, I. A.; Gilman, R. T. \& Boughman, J. W. 2011. Sexual dimorphism and speciation on two ecological coins: patterns from nature and theoretical predictions. Evolution 65(9):2553-2571. 
Costa, W. J. E. M. 1987. Feeding habits of a fish community in a tropical coastal stream, rio Mato Grosso, Brazil. Studies on Neotropical Fauna and Environment 22(3):145-153.

Costa, W. J. E. M. 1995. Revision of the Neotropical Annual Fish Genus Cynopoecilus (Cyprinodontiformes: Rivulidae). Copeia 1995(2):456465.

Costa, W. J. E. M. 1998. Phylogeny and classification of Rivulidae revisited: evolution of annualism and miniaturization in rivulid fishes (Cyprinodontiformes: Aplocheiloidei). Journal of Comparative Biology 3(1):33-92.

Costa, W. J. E. M. 2002a. Peixes Anuais Brasileiros: Diversidade e Conservação. Curitiba, Editora da UFPR. 238p.

Costa, W. J. E. M. 2002b. The annual fish genus Cynopoecilus (Cyprinodontiformes: Rivulidae): taxonomic revision, with descriptions of four new species. Ichthyological Exploration of Freshwaters 13(1):11-24.

Costa, W. J. E. M. 2003. Family Rivulidae (South American annual fishes). In: Reis, R. E.; Kullander, S. O. \& Ferraris JR., C. J. orgs. Check List of the Freshwater Fishes of the South and Central America. Porto Alegre, Edipucrs, p.526-548.

CostA, W. J. E. M. 2008. Catalog of Aplocheiloid killifishes of the world. Rio de Janeiro, UFRJ. 127p.

Costa, W. J. E. M. 2009. Trophic radiation in the South American annual killifish genus Austrolebias (Cyprinodontiformes: Rivulidae). Ichthyological Exploration of Freshwaters 20(2):179-191.

CostA, W. J. E. M. 2016. Comparative morphology and classification of South American cynopoeciline killifishes (Cyprinodontiformes: Aplocheilidae), with notes on family-group names used for aplocheiloids. Vertebrate Zoology 66(2):125-140.

Costa, W. J. E. M.; Amorim, P. F. \& Mattos, J. L. O. 2016. A new species of inseminating seasonal killifish of the Cynopoecilus melanotaenia complex from southern Brazil (Cyprinodontiformes: Rivulidae). Biodiversity Data Journal 4:e6888. doi: 10.3897/BDJ.4.e6888

Costello, M. J. 1990. Predator feeding strategy and prey importance: a new graphical analysis. Journal of Fish Biology 36:261-263.

Davis, W. P.; TAYlor, D. S. \& Turner, B. J. 1990. Field observations of the ecology and habits of mangrove rivulus (Rivulus marmoratus) in Belize and Florida (Teleostei: Cyprinodontiformes: Rivulidae). Ichthyological Exploration of Freshwaters 1(2):123-134.

Dias, T. S. \& Fialho, C. B. 2009. Biologia alimentar de quatro espécies simpátricas de Cheirodontinae (Characiformes, Characidae) do rio Ceará Mirim, Rio Grande do Norte. Iheringia, Série Zoologia 99(3):242-248.

Dias, T. S. \& Fialho, C. B. 2011. Comparative dietary analysis of Eurycheilichthys pantherinus and Pareiorhaphis hystrix: two Loricariidae species (Ostariophysi, Siluriformes) from Campos Sulinos biome, southern Brazil. Iheringia, Série Zoologia 101(1-2):49-55.

Errea, A. \& Danulat, E. 2001. Growth of the annual fish, Cynolebias viarius (Cyprinodontiformes), in the natural habitat compared to laboratory conditions. Environmental Biology of Fishes 61(3):261-268.

García, D.; Loureiro, M. \& TAssino, B. 2008. Reproductive behavior in the annual fish Austrolebias reicherti Loureiro \& García 2004 (Cyprinodontiformes: Rivulidae). Neotropical Ichthyology 6(2):243248.

Gerking, S. D. 1994. Feeding ecology of fish. San Diego, Academic Press. 416p.

Gonçalves, C. S.; Souza, U. P. \& Volcan, M. V. 2011. The opportunistic feeding and reproduction strategies of the annual fish Cynopoecilus melanotaenia (Cyprinodontiformes: Rivulidae) inhabiting ephemeral habitats on southern Brazil. Neotropical Ichthyology 9(1):191-200.

Harrington, R. W. \& Rivas, L. R. 1958. The discovery in Florida of the cyprinodontid fish Rivulus marmoratus, with a redescription and ecological notes. Copeia 1958(1):125-130.

Huehner, M. K.; Schramm, M. E. \& Hens, M. D. 1985. Notes on the behavior and ecology of the killifish Rivulus marmoratus Poey, 1880 (Cyprinodontidae). Florida Science 48:1-7.

Hughes, R. N. 1993. Introduction. In: Hughes, R. N. ed. Diet selection, an interdisciplinary approach to foraging behaviour. Oxford, Blackwell Scientific Publications, p.1-9.

HurLBERT, S. H. 1978. The measurement of niche overlap and some relatives. Ecology 59:67-77.
Hynes, H. B. N. 1950. The food of freshwater sticklebacks (Gasterostomus aculeatus and Pigosteus pungitius), with a review of methods used in studies of the food of fishes. Journal of Animal Ecology 19:36-58.

Hyslop, E. J. 1980. Stomach contents analysis - a review of method and their application. Journal of Fish Biology 17:411-429.

Instituto Brasileiro de Geografa e Estatística. 2004. Mapa da Vegetação e dos Biomas do Brasil. Available at <www.ibge.gov. br>. Accessed on 11 November 2016.

Kapoor, B. C.; Smith, H. \& Verighina, I. A. 1975. The alimentary canal and digestion in teleosts. Advances in Marine Biology 13:109-239.

Karachle, P. K. \& Stergiou, K. I. 2012. Morphometrics and Allometry in Fishes. In: WaHL, C. ed. Morphometrics. InTech Open Access Publisher, p.65-86. Available at <http://www.intechopen.com/books/ morphometrics/morphometrics-and-allometry-in-fishes $>$. Accessed on 11 November 2016.

KaWAKami, E. \& Vazzoler, G. 1980. Método gráfico e estimativa do índice alimentar aplicado no estudo de alimentação de peixes. Boletim do Instituto de Oceanografia 29(2):205-207.

Keast, A. \& WeBb, D. 1966. Mouth and body form relative to feeding ecology in the fish fauna of a small lake, Lake Opinicon, Ontario. Journal of the Fisheries Research Board of Canada 23:1845-1874. KeENLEYSIDE, M. H. A. 1979. Diversity and adaptation in fish behaviour. Berlin, Springer-Verlag. 208p.

Keppeler, F. W.; Lanés, L. E. K.; Rolon, A. S.; Stenert, C.; Lehmann, P.; ReICHARD, M. \& MALTCHIK, L. 2015. The morphology-diet relationship and its role in the coexistence of two species of annual fishes. Ecology of Freshwater Fish 24:77-90.

Keppeler, F. W.; Lanés, L. E. K.; Rolon, A. S.; Stenert, C. \& MaltchiK, L. 2013. The diet of Cynopoecilus fulgens Costa, 2002 (Cyprinodontiformes: Rivulidae) in Southern Brazil wetlands. Italian Journal of Zoology 80:291-302.

KNÖPPEL, H. A. 1970. Food of central Amazonian fishes: contribution to the nutrient-ecology of Amazonian rain Forest streams. Amazoniana 2:257-352.

Kramer, D. L. \& Bryant, M. J. 1995. Intestine length in the fishes of a tropical stream: 1. Ontogenetic allometry. Environmental Biology of Fishes 42:115-127.

KrebS, C. J. 1989. Ecological methodology. New York, Harper Collins Publishers. 654p.

Lanés, L. E. K.; Godoy, R. S.; MaltchiK, L.; PolačIK, M.; BlažEK, R.; VRTíLEK, M. \& ReICHARD, M. 2016. Seasonal dynamics in community structure, abundance, body size and sex ratio in two species of Neotropical annual fishes. Journal of Fish Biology 89(5):2345-2364.

Lanés, L. E. K.; Gonçalves, A. C. \& Volcan, M. V. 2013. Austrolebias arachan Loureiro, Azpelicueta \& García 2004 (Cyprinodontiformes: Rivulidae) in Rio Grande do Sul, Brazil: occurrence, length-weight relationships and condition factor. Journal of Applied Ichthyology 29:252-256.

Lanés, L. E. K.; GonÇalves, A. C. \& Volcan, M. V. 2014a. Discovery of endangered annual killifish Austrolebias cheradophilus (Aplocheiloidei: Rivulidae) in Brazil, with comments on habitat, population structure and conservation status. Neotropical Ichthyology 12:117-124.

Lanés, L. E. K.; Keppeler, F. W. \& Maltchik, L. 2012. Abundance, sexratio, length-weight relation, and condition factor of non-annual killifish Atlantirivulus riograndensis (Actinopterygii: Cyprinodontiformes: Rivulidae) in Lagoa do Peixe National Park, a Ramsar Site of Southern Brazil. Acta Icthyologica and Piscatoria 42:277-252.

Lanés, L. E. K.; Keppeler, F. W. \& MaltchiK, L. 2014b. Abundance variations and life history traits of two sympatric species of Neotropical annual fish (Cyprinodontiformes: Rivulidae) in temporary ponds of southern Brazil. Journal of Natural History 48:1971-1988.

LAnés, L. E. K. \& MaltchiK, L. 2010. Discovery of the annual killifish Critically Endangered, Austrolebias wolterstorffi (Ahl, 1924) (Rivulidae: Cyprinodontiformes) in Lagoa do Peixe National Park, Rio Grande do Sul, southern Brazil. Journal of Threatened Taxa 2(11):1282-1285.

LARKIN, P. A. 1956. Interspecific competition and population control in freshwater fish. Journal of the Fisheries Research Board of Canada 22(6):1357-1377.

Laufer, G.; Arim, M.; Loureiro, M.; Piñero-Guerra, J. M.; ClavijoBAQUET, S. \& FAGÚNDEZ, C. 2009. Diet of four annual killifishes: an intra and interspecific comparision. Neotropical Ichthyology 7(1):77-86. 
Loureiro, M. \& DE SÁ, R. O. 1996. External Morphology of the Chorion of the Annual Fishes Cynolebias (Cyprinodontiformes: Rivulidae). Copeia 1996(4): 1016-1022.

LoureIro, M. \& DE SÁ, R. O. 2016. Diversity of Aplocheiloidei. In: BEROIS, N.; García, G. \& de SÁ, R. O. eds. Annual Fishes: Life History Strategy, Diversity, and Evolution. Boca Raton, Taylor \& Francis, CRC, p. 3-31.

Magnan, P. \& FitzGerald, G. J. 1984. Ontogenetic changes in diel activity, food habits and spatial distribution of juvenile and adult creek chub, Semotilus atromaculatus. Environmental Biology of Fishes 11:301-307.

Maltchik, L.; Lanés, L. E. K.; Stenert, C. \& Medeiros, E. S. F. 2010. Species-area relationship and environmental predictors of fish communities in coastal freshwater wetlands of southern Brazil. Environmental Biology of Fishes 88(1):25-35.

MCCAFFERTY, W. P. 1981. Aquatic Enthomology - The Fishermen's and Ecologist's Ilustrated Guide to Insects and their Relatives. Boston, Jones and Bartlett Publishers. 448p.

Ministério do MeIo Ambiente. 2000. Avaliação e ações prioritárias para a conservação da biodiversidade da Mata Atlântica e Campos Sulinos. Brasília, Ministério do Meio Ambiente. 40p.

Ministério do Meio Ambiente/Secretaria de Biodiversidade E FLORESTAS. 2006. Avaliação e ações prioritárias para a conservação da biodiversidade da Zona Costeira e Marinha. Brasília, Ministério do Meio Ambiente. 72p.

Mugnai, R.; Nessimian, J. L. \& Baptista, D. F. 2009. Manual de identificação de macroinvertebrados Aquáticos do estado do Rio de Janeiro. Rio de Janeiro, Technical Books. 173p.

Munch, S. B. \& Conover, D. O. 2003. Rapid growth results in increased susceptibility to predation in Menidia menidia. Evolution 57:2119-2127.

Myers, G. S. 1952. Annual fishes. Aquarium Journal 23:125-141.

Needham, J. G. \& Needham, P. R. 1978. Guía para el estudio de los seres vivos de las aguas dulces. Barcelona, Editorial Reverte. $131 \mathrm{p}$.

Nico, L. G. \& Thomerson, J. E. 1989. Ecology, food habits and spatial interactions of Orinoco Basin annual killifish. Acta Biologica Venezuelica 12:106-120.

Novakowski, G. C.; HaHn, N. S. \& Fugi, R. 2008. Diet seasonality and food overlap of the fish assemblage in a Pantanal pond. Neotropical Ichthyology 6:567-576.

Ortiz, E. \& ARIM, M. 2016. Hypotheses and trends on how body size affects trophic interactions in a guild of South American killifishes. Austral Ecology 41(8):976-982.

Persson, L. 1987. The effects of resource availability and distribution on size class interaction in perch, Perca fluviatilis. Oikos 48:148-160.

Pilatti, A. \& Vanni, M. J. 2007. Ontogeny, diet shifts, and nutrient stoichiometry in fish. Oikos 116(10):1663-1674.

PolačIK, M.; DONNER, M. T. \& ReICHARD, M. 2011. Age structure of annual Nothobranchius fishes in Mozambique: Is there a hatching synchrony? Journal of Fish Biology 78:796-809

PolaČIK, M. \& ReICHARD, M. 2010. Diet overlap among three sympatric African annual killifish species Nothobranchius spp. from Mozambique. Journal of Fish Biology 77:754-768.

Popova, O. A. 1967. The 'predator-prey' relationship among fish. In: GERKING, S. D. ed. The biological basis of freshwater fish production. Oxford, Blackwell Scientific Publications, p.359-376.

Popova, O. A. 1978. The role of predaceous fish in ecosystems. In: GERKING, S. D. ed. Ecology of freshwater fish production. New York, John Wiley \& Sons, p.215-249.

Pyke, G. H.; Pulliam, H. R. \& Charnov, E. L. 1977. Optimal foraging: a selective review of theory and tests. The Quarterly Review of Biology 52:137-154

Ramos-Jiliberto, R.; VAldovinos, F. S.; Arias, J.; Alcaraz, C. \& GarcíaBerthou, E. 2011. A network-based approach to the analysis of the ontogenetic diet shifts: an example with na endangered, small-sized fish. Ecological Complexity 8:123-129.

Reis, R. E.; Lucena, Z. M. S.; Lucena, C. A. S. \& Malabarba, L. R 2003. Peixes. In: Fontana, C. S.; Bencke, G. A. \& Reis, R. E. eds. Livro Vermelho da Fauna Ameaçada de Extinção no Rio Grande do Sul. Porto Alegre, Edipucrs, p.117-145.

Rezsu, E. \& Specziár, A. 2006. Ontogenetic diet profiles and size-dependent diet partitioning of ruffe Gymnocephalus cernuus, perch Perca fluviatilis and pumpkinseed Lepomis gibbosus in Lake Balaton. Ecology of Freshwater Fish 15:339-349.

Roff, D. A. 1992. The Evolution of Life Histories: Theory and Analysis. NewYork, Chapman \& Hall. 535p.

Rosa, R. S. \& Lima, F. C. T. 2008. Peixes. In: Machado, A. B. M.; Drummond, G. M. \& Paglia, A. P. eds. Livro vermelho da fauna brasileira ameaçada de extinção. Brasília, Ministério do Meio Ambiente, p.9-285.

Rueffer, C.; Van Dooren, T. J. M.; Leimar, O. \& Abrams, P. A. 2006. Disruptive selection and then what? Trends in Ecology \& Evolution 21(5):238-245

SÁnchez-Hernández, J. \& Cobo, F. 2012. Summer differences in behavioural feeding habits and use of feeding habitat among brown trout (Pisces) age classes in a temperate area. Italian Journal of Zoology 79(3):468-478.

Sánchez-Hernández, J.; Servia, M. J.; Vieira-Lanero, R. \& Cobo, F. 2012. Ontogenetic Dietary Shifts in a Predatory Freshwater Fish Species: The Brown Trout as an Example of a Dynamic Fish Species. In: TURKER, H. ed. New Advances and Contributions to Fish Biology. InTech, p.271-298. Available at <http://www.intechopen.com/books/ new-advances-and-contributions-to-fish-biology>. Accessed on 11 November 2016.

Sánchez-Hernández, J.; Vieira-Lanero, R.; Servia, M. J. \& Cobo, F. 2011. First feeding diet of young brown trout fry in a temperate area: disentangling constraints and food selection. Hydrobiologia 663(1): 109-119.

Santos-Filho, P. S. 1997. The effect of body size on prey choice by Rivulus luelingi Seegers 1984 (Aplocheiloidei: Rivulidae). Revista Brasileira de Biologia 57(4):551-562.

Schafer, L. N.; Platell, M. E.; Valesini, F. J. \& Potter, I. C. 2002. Comparisons between the influence of habitat type, season and body size on the dietary compositions of fish species in nearshore marine waters. Journal of Experimental Marine Biology and Ecology 278:67-92.

Schoener, T. W. 1974. Resource Partitioning in Ecological Communities. Science 185(4145):27-39.

ShibatTA, A. O. 2005. Reprodução do pirá-brasília, Simpsonichthys boitonei Carvalho (Cyprinodontiformes, Rivulidae), e caracterização de seu habitat na Reserva Ecológica do Instituto Brasileiro de Geografia e Estatística, Brasília, Distrito Federal, Brasil. Revista Brasileira de Zoologia 22:1146-1151.

Shibatta, A. O. 2006. Comportamento social do pirá-brasília, Simpsonichthys boitonei Carvalho (Cyprinodontiformes, Rivulidae). Revista Brasileira de Zoologia 23:375-380.

Shibatta, A. O. \& Bennemann, S. T. 2003. Plasticidade alimentar em Rivulus pictus Costa (Osteichthyes, Cyprinodontiformes, Rivulidae) de uma pequena lagoa em Brasília, Distrito Federal, Brasil. Revista Brasileira de Zoologia 20:615-618.

ShibatTA, A. O. \& RochA, A. J. A. 2001. Alimentação em machos e fêmeas de Simpsonichthys boitonei Carvalho (Cyprinodontiformes, Rivulidae). Revista Brasileira de Zoologia 18:381-385.

SHINE, R. 1989. Ecological Causes for the Evolution of Sexual Dimorphism: A Review of the Evidence. The Quarterly Review of Biology 64(4):419-461.

Sogard, S. M. 1997. Size-selective mortality in the juvenile stage of teleost fishes: a review. Bulletin of Marine Science 60:1129-1157.

TAYLOR, D. S. 1992. Diet of the killifish Rivulus marmoratus collected from land crab burrows, with further ecological notes. Environmental Biology of Fish 33:389-393.

Teixeira de Mello, F.; Iglesias, C.; Borthagaray, A. I.; Mazzeo, N.; Vilches, J.; LaRrea, D. \& Ballabio, R. 2006. Ontogenic allometric coefficient changes. Implicances of diet shift and morphometric attributes in Hoplias malabaricus (Bloch) (Characiformes, Erythrinidae). Journal of Fish Biology 69:1770-1778.

Vaz-Ferreira, R.; Sierra de Soriano, B. \& Señorans, J. S. 1966. Integracion de la fauna de vertebrados em algunas masas de agua dulce temporales del Uruguay. Compendios de Trabajo del Departamento de Zoologia Vertebrados de la Facultad de Humanidades y Ciencias 25:1-16.

VIEIRA, S. 1991. Introdução à Bioestatística. Rio de Janeiro, Editora do Campus. 294p.

Violle, C.; Enquist, B. J.; McGill, B. J.; Jiang, L.; Albert, C. H.; 
Hulshof, C.; Jung, V. \& Messier, J. 2012. The return of the variance: intraspecific variability in community ecology. Trends in Ecology and Evolution 27(4):244-252.

Volcan, M. V.; GonÇAlves, A. C. \& Lanés, L. E. K. 2011. Distribution, habitat and conservation status of two threatened annual fishes (Rivulidae) from southern Brazil. Endangered Species Research 13:79-85

Volcan, M. V.; Gonçalves, A. C.; Lanés, L. E. K. \& Guadagnin, D. L. 2015. Annual Fishes (Rivulidae) from Southern Brazil: A BroadScale Assessment of their Diversity and Conservation. In: BEROIS, N.; García, G. \& de Sá, R. O. eds. Annual Fishes: Life History Strategy, Diversity, and Evolution. Boca Raton, Taylor \& Francis, CRC, p.185-203.

Volcan, M. V.; Lanés, L. E. K. \& Cheffe, M. M. 2010. Distribuição e Conservação de Peixes Anuais (Cyprinodontiformes, Rivulidae) no município do Chuí, Brasil. Biotemas 23(4):51-58.

Wainwrigth, P. C. \& Richard, B. A. 1995. Predicting patterns of prey use from morphology of fishes. Environmental Biology of Fishes 44:97-113.

Ward, A. J. W.; Webster, M. M. \& Hart, P. J. 2006. Intraspecific food competition in fishes. Fish and Fisheries 7:231-261.

Werner, E. E. \& Gilliam, J. F. 1984. The ontogenetic niche and species interactions in size-structured populations. Annual Review of Ecology and Systematics 15:393-425.
Winemiller, K. O. 1989. Ontogenetic diet shifts and resource partitioning among piscivorous fishes in the Venezuelan llanos. Environmental Biology of Fishes 26:177-199.

Winemiller, K. O. \& JePsen, D. B. 1998. Effects of seasonality and fish movement on tropical river foodwebs. Journal of Fish Biology 53:267-296.

Winemiller, K. O. \& Kelso-Winemiller, L. C. 2003. Food habits of tilapinae cichlids of the Upper Zambezi river and floodplains during the descending phase of the hydrological cycle. Journal of Fish Biology 63:120-128.

Woodward, G. \& Hildrew, A. G. 2002. Body size determinants of niche overlap and intraguild predation within a complex foodweb. Journal of Animal Ecology 71:1063-1074.

Wootton, J. H. 1999. Ecology of teleost fish. Dordrecht, Kluwer Academic Publishers. 386p.

Wourms, J. P. 1972. The developmental biology of annual fishes. III. Pre embryonic and embryonic diapause of variable duration in the eggs of annual fishes. Journal of Experimental Zoology 182:389-414.

XuE, Y.; Jin, X.; Zhang, B. \& Liang, Z. 2005. Seasonal, diel and ontogenetic variation in feeding patterns of small yellow croaker in the central Yellow Sea. Journal of Fish Biology 67:33-50.

ZARET, T. M. \& RAND, S. S. 1971. Competition in tropical streams: support for the competititve exclusion principle. Ecology 52:336-342.

ZAVALA-CAMIM, L. A. 1996. Introdução aos estudos sobre alimentação natural em peixes. Maringá, EDUEM. 129p. 